(東京大学理工学研究所, 東京都目黒区) (昭和 28 年 11 月 19 日受理)

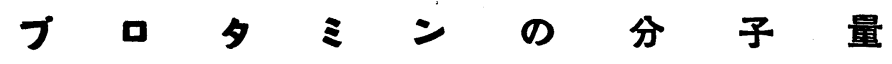

磯 晃二郎*・北村とも于・渡辺格

プロタミンは天然蛋白質中最も簡単なもので1)，これ の研究は蛋白質化学にとって意義深いものでせる。一般 にプロタミンは細胞核内で高分子量の核酸と結合して巨 大核蛋白貿を形成していると考えられている2゙。このこ とからも，その分子状態の研究は重要なものである。

徉来, 化学的研究は比較的多く行われているが, 分子 量等に関する物理化学的研究は少なく, アミノ酸分析そ の他等から得られた最小分子量はニシンのクルペインに ついて約 $2,000 〜 4,000$, サケのサルミンについて約7,000 〜9,000 位といわれ, 又安藤等はサルミン区びクルペイ
ンが共に同じ程度の分子量で約て,000 位であると報告し ている(第 1 表)。

本報ではニシンの白子より調製したクルペイン硫酸塩 及びサケの白子より調製したサルミン硫酸塩について， 拡散及び粘度の测定によって得られた分子量，形状等に 閔する結果を述べる。

I. 実

験

試 料 本実験で用いたサルミンはサタの白子，クル ペインはニシンの白子より採取した精虫からそれぞれ

第 1 表 プロ》ミン心分子齿データ

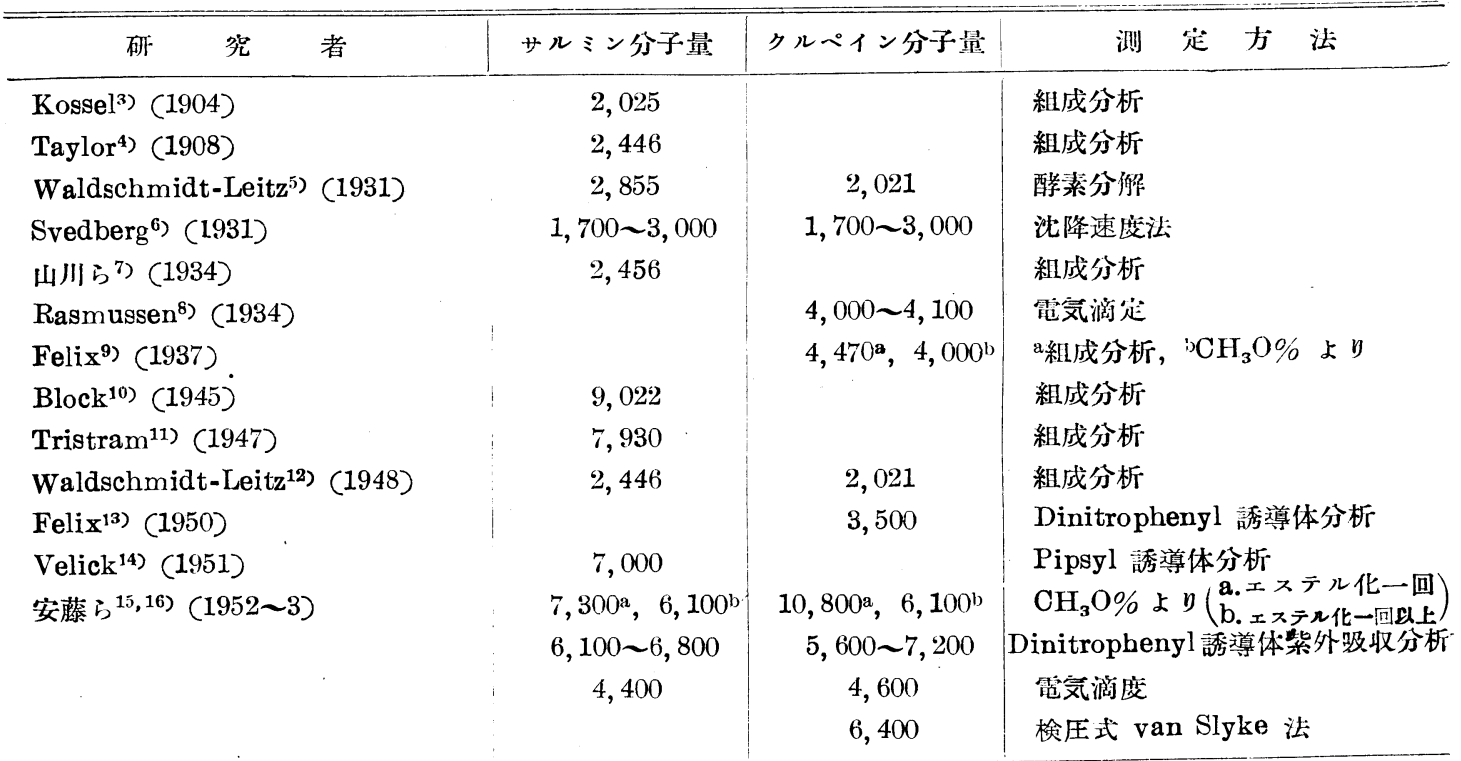

* 現在東京大学敉養学部化学敉室.

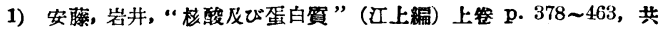
立出肘 (1951).

2）没辺，鉿木，“核酸及び蛋白贵”（江上編）」管 p. 165 250，共 立出服 (1951).

3) A. Kossel, H. D. Dakin, Z. physiol. Chem. 41, 407 (1904).

4) A. E. Taylor, J. Biol. Chem. 5, 389 (1908 9).

5) E. Waldschmidt-Leitz, F. Ziegler, A. Schäff ner, L. Weil, Z. physiol. Chem. 197, 219 (1931).

6) T. Svedberg et al., 文献 5) に引用.

7) 山川, 西沢, 水講 30, 83 (1934)

8) K. E. Rasmussen, Z. physiol. Chem. 224, 97 (1937).
9) K. Felix, A. Mager, $Z$, physiol. Chem. 249, 111 (1937).

10) R. J. Block, D. Bolling, Arch. Biochem. 6, 419 (1945).

11) G. R. Tristram, Nature 160, 637 (1947).

12) E. Waldschmidt-Leitz, E. Günther, Makromol. Chem. 2, 12) (1948).

13) K. Felix, H. Fischer, A. Krekels, H. M. Rauen, Z. physiol. Chem. 286, 67 (1950).

14) S. F. Velick, S. Udenfriend, J. Biol. Chem. 191, 233 (1951).

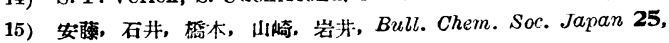
132 (1952).

16) 安藤, 岩井, 山崎, 楅本, 木村, 石井, 田村, Bull. Chem. Soc Japan 26, 406 (1953). 
Rasmussen $^{8)}$ の方法に往って塩酸で抽出を行い,ピク リン酸塩を経て硫酸塭として精製された試料で，クルぺ

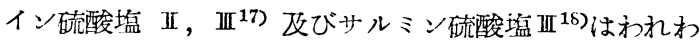
れの研究室で調製したものであり，いずれも電気泳動的 に均一である ${ }^{19)}$ 。クルペイン硫酸睢 $\mathrm{A}$ は当研究所の安藤 教授より提供されたもので， $\mathbf{A}_{\mathbf{2}}$ は同氏により特にアル ミナ吸着により分別された試料で交る。

拡散定数の測定 方法は既に靖告した通りで20), Neurath 型の抎散れル21)を使用して Philpot-Svensson の シェリーレン法を用いた濃度勾配直視装置を用いる光学 的方法によった。

溶媒としては㧓散粒子の街電による影䡒を調べるため に水及び種々のイオン強度の綏街液を用い, $\mathrm{pH} 7.7$, イ オン虺度 0.2 の憐酸掹緩衝液では濃度零での值を求め るために，濃度変化についても测定を行った。濃度勾配 曲線より拡散定数を求めるには次の計算法を用いて得た 値を $20^{\circ} \mathrm{C}$ の水中での值 $D_{20 w}$ に拁算した ${ }^{23)}$ 。

(i) 変曲点法 $\quad D_{\mu}=\frac{\mu^{2}}{2 t} \times F$

(ii) 面積法

$$
D_{A}=\frac{A^{2}}{4 \pi t\left(H_{m}\right)^{2}} \times F
$$

(iii) 統計的能摔法 $D_{M}=\frac{\sigma^{2}}{2 t} \times F$

ここて $\mu$ は繁曲点の高さに拈ける半值门， $F$ は拡大補 正因子， $A$ は曲線の占める面積， $H_{m}$ は曲線の高さ (原 点座標), $t$ は拡散溡間 (単位秒)， $\sigma$ は曲線の原点に関 する標準偏差で女る。な拈 (iii)より直接濃度零の拡散

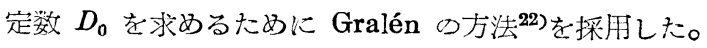
即ち

$$
D_{0}=D_{M}\left(1+\frac{5 X_{m}}{Y_{m}}\right)
$$

ここで $X_{m}$ 友び $Y_{m}$ は観測曲線を正準变換して得られ た曲線の䫏点座標でむる。

粘度則定 Ostwald 粘度計を脚いて $20^{\circ} \mathrm{C}$ に扣ける 種々なる濃度 $c$ の比粘度 $\eta_{s p}$ を测定し, $\eta_{s p} / c$ を濃度零 に外插した。この外插值に偏比容積 $V$ として一般蛋白 筫の值 $V=0.74$ を仮定して容稹国有战度

$$
[\eta]_{v}=\lim _{c \rightarrow 0}\left(\eta_{* p} / c\right) / V
$$

1i）鉿木，浬辺 本誌 73，825 (19;2)。

18）哙木, 東大理工学呼究所绑告 4, 231 (1950).

19) 宇井, 波辺, 本誌 74, 647 (1953).

20) 渡辺, 磯, 科学 18, 421 (1948).

21) H. Neurath, Science 93, 431 (1941).

22) N. Gralén, Dissertatíon, Uppsala (1944), х 丸 A. F. Schick, S. J. Singer, J. Phys. Colloid Chem. 54, 1028 (1950).

23) H. Neurath, Chem. Revs. 30, 357 (1942).
を求めた。

分子至及び分子形の出出 分子量 $M$ と拡散定数 $D$ と の間には次の関係が安る ${ }^{23)}$ 。

$$
\begin{aligned}
& M= \frac{R^{3} T^{3}}{162 \pi^{2} N^{2} \eta^{3}} \cdot \frac{1}{\left(f / f_{0}\right)^{3}} \cdot \frac{1}{V D^{3}} \\
&= 2.3_{4} \times 10^{-14} \cdot \frac{1}{\left(f / f_{0}\right)^{3}} \cdot \frac{1}{V D^{3}} \\
&\left(20^{\circ} \mathrm{C} \text { の水にて }\right)
\end{aligned}
$$

ここで $R$ は気体定数， $T$ は絶対温度， $N$ は Avogadro 数，凤は溶媒の粘度, $f / f_{0}$ は分子の摩擦比 (frictional ratio), $V$ は溶筫の偏比容積 (partial specific volume) である。

著者等は $f / f_{0}$ を粘度より求めた。即ち分子を棒状廻 転棈円体と仮定して固有粘度 $[\eta]_{v}$ より Simba の理論 式24)用いて分子の朝比 $b / a$ ( $a$ は棈円体の短朝, $b$ は 長㜞の長さでまる) を求め，次に軸比と摩擦比とについ ての Perrin の式 ${ }^{25}$ 加，相当する摩擦比 $f / f_{0}$ が計算 される。この值と $D$ 及び $V$ の值を上式に代入して分 子量が求められ， $M, V$ 及び $b / a$ の値から达式によっ て $a$ 友び $b$ なる軸の長さが計算される。

$$
a=\left[\frac{6 M V}{\pi N(b / a)}\right]^{1 / 3}
$$

\section{II. 結果及び考察}

クルペイン硫酸塩友びサルミン硫酸塭の昖散定数の测 定值をそれぞれ第2表及び第3袁に示した。この表から 判るようにクルペインもサルミンも其に溶媒中の中性湓 濃度が増すにつれて，㧓散定数は減少して遂には一定の 值に達することが見られる(第1図)。

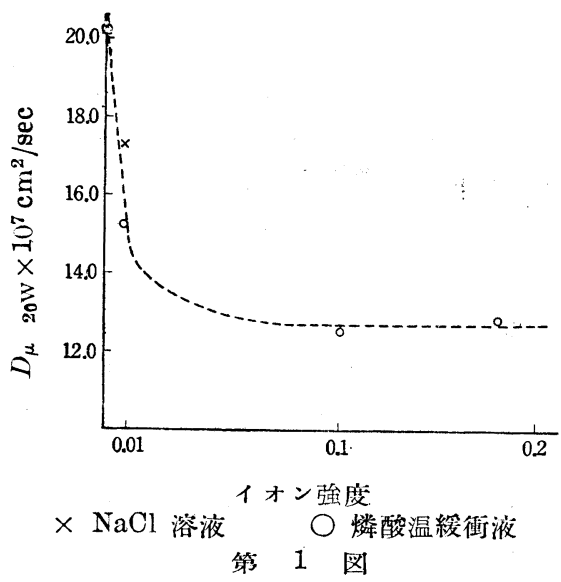

24) R. Simha, J. Phys. Chem. 44, 25 (1940).

25) T. Svedberg, K. O. Pedersen, "The Ultracentrifuge" Oxford p. 41 (1940). 
第 2 表 クルペイン硫酸程の拡散定数

\begin{tabular}{|c|c|c|c|c|c|c|c|c|}
\hline \multirow{2}{*}{ 試 } & \multirow{2}{*}{ 料 } & \multirow{2}{*}{ 溶 } & \multirow{2}{*}{$\mathrm{pH}$} & \multirow{2}{*}{$\begin{array}{l}\text { 濃度 } \\
\text { (重量\%) }\end{array}$} & \multicolumn{4}{|c|}{$D_{20 w} \times 10^{7} \mathrm{~cm}^{2} / \mathrm{sec}$} \\
\hline & & & & & $D_{\mu}$ & $D_{A}$ & $D_{M}$ & $D_{i}$ \\
\hline & $A_{1}$ & 水 & - & 約 1.2 & 20.2 & & & \\
\hline & III & "I & - & 0.44 & $24 \cdot 2$ & 22.2 & $19 \cdot \mathbf{3}$ & $19 \cdot 3$ \\
\hline & $A_{2}$ & $\mu=0.2$, P.B. & 7.7 & 約 0.5 & 12.2 & & & \\
\hline & $A_{3}$ & " " & " & 約 0.4 & $11 \cdot 6$ & & & \\
\hline & II & " & $" \prime$ & 0.47 & 10.9 & 10.5 & 9.8 & $10 \cdot 5$ \\
\hline & III & " & " & 0.32 & 12.4 & $12 \cdot \mathbf{3}$ & 11.8 & $12 \cdot 1$ \\
\hline & III & " " & "l & 0.24 & 約 13 & $12 \cdot 4$ & 11.1 & 11.7 \\
\hline & III & $\mu=0.4$, P.B. $+\mathrm{NaCl}$ & " & 0.43 & $13 \cdot 1$ & & & \\
\hline
\end{tabular}

註 P.B. = 燐酸塩緩衝液

第 3 表 サルミン硫酸塩 III の拡散定数

\begin{tabular}{|c|c|c|c|c|c|c|}
\hline \multirow{2}{*}{ 溶桇 } & \multirow{2}{*}{$\mathrm{pH}$} & \multirow{2}{*}{$\begin{array}{cc}\text { 濃 } & \text { 度 } \\
(\text { 重量 } \%)\end{array}$} & \multicolumn{4}{|c|}{$D_{20 w} \times 10^{7} \mathrm{~cm}^{2} / \mathrm{sec}$} \\
\hline & & & $D_{\mu}$ & $D_{A}$ & $D_{M}$ & $D_{0}$ \\
\hline 水 & - & 0.48 & $20 \cdot 2$ & & & \\
\hline 0.01 mole $\mathrm{NaCl}$ & - & 0.54 & $17 \cdot \mathbf{3}$ & & & \\
\hline$\mu=0.01$, P.B. & 7.6 & 0.44 & $15 \cdot 2$ & & & \\
\hline$\mu=0.1, \quad$ P.B. & 7.7 & 0.47 & $12 \cdot 5$ & & & \\
\hline$\mu=0.2, \quad$ A.B. & 5.0 & 0.51 & $12 \cdot 6^{*}$ & & & \\
\hline$\mu=0.2, \quad$ P.B. & 7.7 & 0.51 & $12 \cdot \mathbf{3}$ & $12 \cdot 0$ & $11 \cdot 3$ & 11.6 \\
\hline " & " & 0.45 & $12 \cdot 8$ & $12 \cdot 2$ & $11 \cdot 6$ & $12 \cdot 3$ \\
\hline " " & $" 1$ & 0.27 & $13 \cdot 1$ & $12 \cdot 9$ & $12 \cdot 5$ & $12 \cdot 6$ \\
\hline$\mu=0.4, \quad$ P.B. $+\mathrm{NaCl}$ & $"$ & 0.46 & $13 \cdot 8$ & $13 \cdot \mathbf{s}$ & $12 \cdot 5$ & $12 \cdot 7$ \\
\hline
\end{tabular}

註 P.B. =燐酸塩緩衝液, A.B. =酢酸塩緩衝液, * は緩衝液中の值.

このことは水中でプロタミン硫酸壏の解離によって生じ た正貧イオン間に相互作用が㗢いて, 単独では拡散の速 い硫酸イオンと拡散の遅いプロタミンイオンが見掛上中 間の速さで一緒に動くように芫える。これに中性壏が加 えられると睢濃度の增加と共に次第にその相互作用が遮 蔽され遂には打消されるようになると考えられる。この ことは理論的に予想されることと一致する。表から明ら かなようにイオン強度 0.1 以上では電荷の影響は殆んど 打消されると考穴られる。かくして $\mathrm{pH} 7.7$, イオン強度 $\mu=0.2$ の憐酸壏緩衝液について得られた拡散定数はク ルペイン硫酸塩正について $12 \times 10^{-7} \mathrm{~cm}^{2} / \mathrm{sec}$, サミン 硫酸塩 IIIついては平均值 $12.2 \times 10^{-7} \mathrm{~cm}^{2} / \mathrm{sec}$ でする。 今ここに得られた拡散定数と粘度測定から求めた固有 粘度とを用いて，その分子量等を算出するに際して次の ことを考える必要が女ると思われる。クルペインもサル

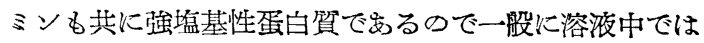

プロタミンと硫酸基とは可成の程度の解離が起っている と考えられる。よって払散更び粘性過程に扎いて上記の 条件で求めた分子定数がプロタミン硫酸塩のbのと見做 されるべきか，岕るいは遊離プロタミンイオンのそれと 見做されるべきかについて䦗題が安る。この点について は現在研究中でをるが，本報では一応兆者の立場で分子 状態の算出を試みた。

第 4 表及び第 5 表にそれぞれクルペイン硫酸墔及びサ ルミン硫酸㷪の $D_{20 w},[\eta]_{v}$ の実测值と, これより計算 した $M, b / a, f / f_{0}, a$ 不び $b$ 值を示した。今クルค・ インについて硫酸嫶と考えた場合と遊離イオンと考えた 場合について計算した分子量を比較して見ると，表から 判るようにその奎は 1600 (=7200-5600)で，これは化 学分析值から推定されるように主として含有硫酸基 (約 20\%) வ分子量に帰せられるように思われる。徉って クルペイン自体の分子量はいずれの見地加計算しても 


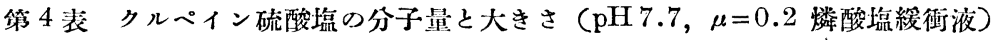

\begin{tabular}{l|r|r|r|r|r|r|r|r}
\hline & $D_{0} \times 10^{7}$ & {$[\eta]$} & $b / a$ & $f / f_{0}$ & $V$ & $M$ & $a(\AA)$ & $b(\AA)$ \\
\hline 水和なし & 12.0 & $8.6_{5}$ & 7.0 & $1.3_{8}$ & $(0.74)$ & $7,200(5800) \dagger$ & 13 & 94 \\
水和 $0.2 \mathrm{~g} \mathrm{H} \mathrm{H}_{2} \mathrm{O} / \mathrm{g} \mathrm{Pr}$. & $\prime \prime$ & $\prime \prime$ & 5.9 & $1.3_{1}$ & $(0.78) *$ & $8,000(6400) \dagger$ & 15 & 88 \\
水和 $0.4 \mathrm{~g} \mathrm{H} \mathrm{H}_{2} \mathrm{O} / \mathrm{g} \mathrm{Pr}$ Pr & $\prime \prime$ & $\prime \prime$ & 4.9 & $1.2_{5}$ & $(0.82) *$ & $8,800(7000) \dagger$ & 17 & 82 \\
\hline クルペインイオンとして & 12.0 & 12.5 & 9.2 & $1.5_{0}$ & $(0.74)$ & 5600 & 11 & 104 \\
\hline
\end{tabular}

* は水和のない偏比谷楥を 0.74 と仮定して計算した。 †括弧內は遊離クルペインイォンとしての換算值.

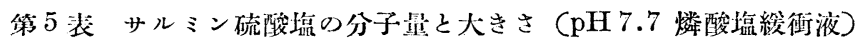

\begin{tabular}{l|r|r|r|r|c|c|c|c}
\hline & $D_{0} \times 10^{7}$ & {$[\eta]$} & $b / a$ & $f / f_{0}$ & $V$ & $M$ & $a(\AA)$ & $b(\AA)$ \\
\hline 水和なし,$\mu=0.2$ & 12.2 & 9.2 & 7.4 & 1.40 & $(0.74)$ & $6,600(5300) \dagger$ & 13 & 96 \\
水和なし $\mu=0.4$ & 12.7 & 8.5 & 6.9 & 1.37 & $(0.74)$ & $6,200(5000) \dagger$ & 13 & 87 \\
\hline
\end{tabular}

$\dagger$ 括弧队遊離サルミンイオンとしての換算值.

誤差範画で一致しているといえる。水和については二つ の水和量を仮定して，これに基づいて测定した固有粘度 值から期此を計算するには，Oncley ${ }^{26)}$ の種々なる固有 粘度に封する水和と分子の軸比の関係を示したグラフに よって行った。

ヌサルミン硫酸㙁について第 5 表から溶媒のイオン强 度が異なっても，得られた分子量は誤差戦围で一致して いることが認められる。

以上のことからクルペイン㞋びサルミンの雨者につい て比較して見ると，分子量の点で同者はほほ同等で電気 泳動的にも区別できない承実 ${ }^{19}$ と符号している。そして 硫酸掹としての分子量は水和がないとすれば 6,000 7,000 程度で, 遊離蛋白としては5,000〜6,000程度である。

次に棒状趈転楕円体と仮定したときの短軸の長さは $13 \AA$ で，この值は既にゼラチン27)や合成ぺプチド28)に ついて X 總的研究から求められたペプチドの側鎖間隔 $12 \AA$ より $15 \AA$ の值に比較すれば，合理的な子のと思 われる。即ちこの場合には一本のペプチド鎖と考えられ

26) J. L. Oncley, Ann. New York Acad. Sci. 41, 121 (1941).

27) O. L. Sponsler, J. D. Bath, J. W. Ellis, J. Phys. Chem. 44, 996 (1940).

28 ) C. H. Bamford, W. E. Hanby, F. Happey, Proc. Roy. Soc. A 205, 30 (195!).
る。

な扎円盤状迴転棈円体と伛定すると厚さが $5 \AA$ 位に なり明らかに不合理である。

\section{III. 総括}

シシンの白子から調製したクルペイン硫酸塩区びサケ の白子から調製したサルミン碚酸壏について，拡散及び 粘度の測定を行い，電解資としての性質を考蚛して分子 量, 分子形等を算开し，雨者は分子量の点で活ぼ同等で

$D_{2 \mathrm{o} w} \fallingdotseq 12 \times 10^{-7} \mathrm{~cm}^{2} / \mathrm{sec}$

$[\eta]_{v}=9$

水和のない棒状分子として

$$
\begin{array}{r}
M=6,000 \sim 7,000 \text { (硫酸檌として) } \\
5,000 \sim 6,000 \text { (遊離蛋白として) }
\end{array}
$$

ウ $13 \AA$ ，長さ $90 \AA$ ないし $100 \AA$ なる值を得た。

終りに本咘究を行らに当りクルペイン硫酸知の試料を 御提供下され，又分子量表について御指示を戴く等種々 御嗳助下さった当研究所安藤鈖郎教授に厚く感謝の意を 表わしまず。

な扣本研究は文部省科学破労費によって行ったもので ここに厚く謝意を表する。

（昭和 27 年 4 月，日本化学全第 5 年会講演） 